\title{
Endocrine pancreatic development: impact of obesity and diet
}

\author{
Jacqueline F. O'Dowd* and Claire J. Stocker \\ Metabolic Diseases Group, Clore Laboratory, University of Buckingham, Buckingham, UK
}

\section{Edited by:}

Catalina Pico, University of the

Balearic Islands, Spain

Reviewed by:

Janna L. Morrison, University of

South Australia, Australia

Andrew L. Siebel, Baker IDI Heart

and Diabetes Institute, Australia

*Correspondence:

Jacqueline F. O'Dowd, Clore

Laboratory, University of

Buckingham, Hunter Street,

Buckingham, MK18 1EG, UK

e-mail: jacqueline.odowd@

buckingham.ac.uk
During embryonic development, multipotent endodermal cells differentiate to form the pancreas. Islet cell clusters arising from the pancreatic bud form the acini tissue and exocrine ducts whilst pancreatic islets form around the edges of the clusters. The successive steps of islet differentiation are controlled by a complex network of transcription factors and signals that influence cell differentiation, growth and lineage. A Westernized lifestyle has led to an increased consumption of a high saturated fat diet, and an increase in maternal obesity. The developing fetus is highly sensitive to the intrauterine environment, therefore any alteration in maternal nutrition during gestation and lactation which affects the in-utero environment during the key developmental phases of the pancreas may change the factors controlling $\beta$-cell development and $\beta$-cell mass. Whilst the molecular mechanisms behind the adaptive programming of $\beta$-cells are still poorly understood it is established that changes arising from maternal obesity and/or over-nutrition may affect the ability to maintain fetal $\beta$-cell mass resulting in an increased risk of type 2 diabetes in adulthood.

Keywords: maternal over-nutrition, obesity, developmental programming, pancreas, transcription factors

\section{INTRODUCTION}

The pancreas is composed of both exocrine and endocrine tissue. The exocrine gland secretes digestive enzymes while the endocrine gland, which consists of the islets of Langerhans, secretes hormones into the bloodstream. Each individual islet is composed of a number of endocrine cells specializing in the secretion of specific hormones (Bonner-Weir and Orci, 1982). There are four main endocrine cells contained within an islet: insulin producing $\beta$-cells; $\alpha$-cells, which produce glucagon; $\delta$ cells, which produce somatostatin and PP-cells, which secrete pancreatic polypeptide.

The development of the pancreas is a complex process. During embryogenesis the pancreas is derived from the gut and a cascade of signaling processes acts on precursor cells to determine their cell fate generating both exocrine and endocrine cells prior to birth. In rodents, $\beta$-cell neogenesis, the generation of new $\beta$-cells (Paris et al., 2004) continues throughout neonatal life, but ceases shortly after weaning (Deltour et al., 1991). Any environmental stress or stimulus during these critical periods of early development can permanently alter endocrine mass and $\beta$-cell function resulting in long-term health consequences in the developing infant (McMillen and Robinson, 2005).

Over recent decades there has been a rapid rise in metabolic disorders throughout the world. A Westernized lifestyle and societal habits have contributed to the obesity and type 2 diabetes epidemics. The WHO estimates that in 2008 there were more than 1.4 billion overweight adults worldwide, 500 million of which

Abbreviations: Rodent gene symbols are italicized, with only the first letter in uppercase and the remaining letters in lowercase while rodent protein symbols are not italicized and all are upper case. Human gene symbols are italicized, with all letters in uppercase. are obese (WHO, 2013). As the number of obese individuals increase, and in particular in women of child-bearing age, so does the rate of obese pregnancies. There is now increasing evidence that the early developmental environment of an infant can play a pivotal role in the "programming" of an adverse physiological phenotype in later life. Clinical evidence highlights that maternal over-nutrition and/or obesity presents not only adverse effects on maternal health, but also persistent and deleterious effects in the developing child (Nelson et al., 2010; Alfaradhi and Ozanne, 2011; Poston, 2012; Rkhzay-Jaf et al., 2012) (Figure 1).

In clinical studies it is harder to dissect out the effects of maternal obesity from those of an obesogenic diet, however, this can be addressed in animal models. Animal models provide essential insight into the underlying cellular and molecular mechanisms that contribute to this adverse phenotype. The majority of research has focused on sheep and rodents $(\mathrm{Li}$ et al., 2011). While many developmental events occur postnatally in rodents, the short gestation period, development of the metabolic syndrome within months, cost effectiveness and longitudinal nature of these studies, means that rodents are the most commonly used models (Alfaradhi and Ozanne, 2011). Sheep and non-human primates do offer advantages because of the similarities of their developmental patterns to humans; however, long gestation periods and high costs make them less available. The information gained from these animal studies not only aids our understanding of the programming signals related to maternal and paternal over-nutrition but may enable the improved healthcare for both mother and infant. This review will firstly describe the development of the pancreatic $\beta$-cell and will then examine the impact of developmental programming as a result of maternal over-nutrition on 


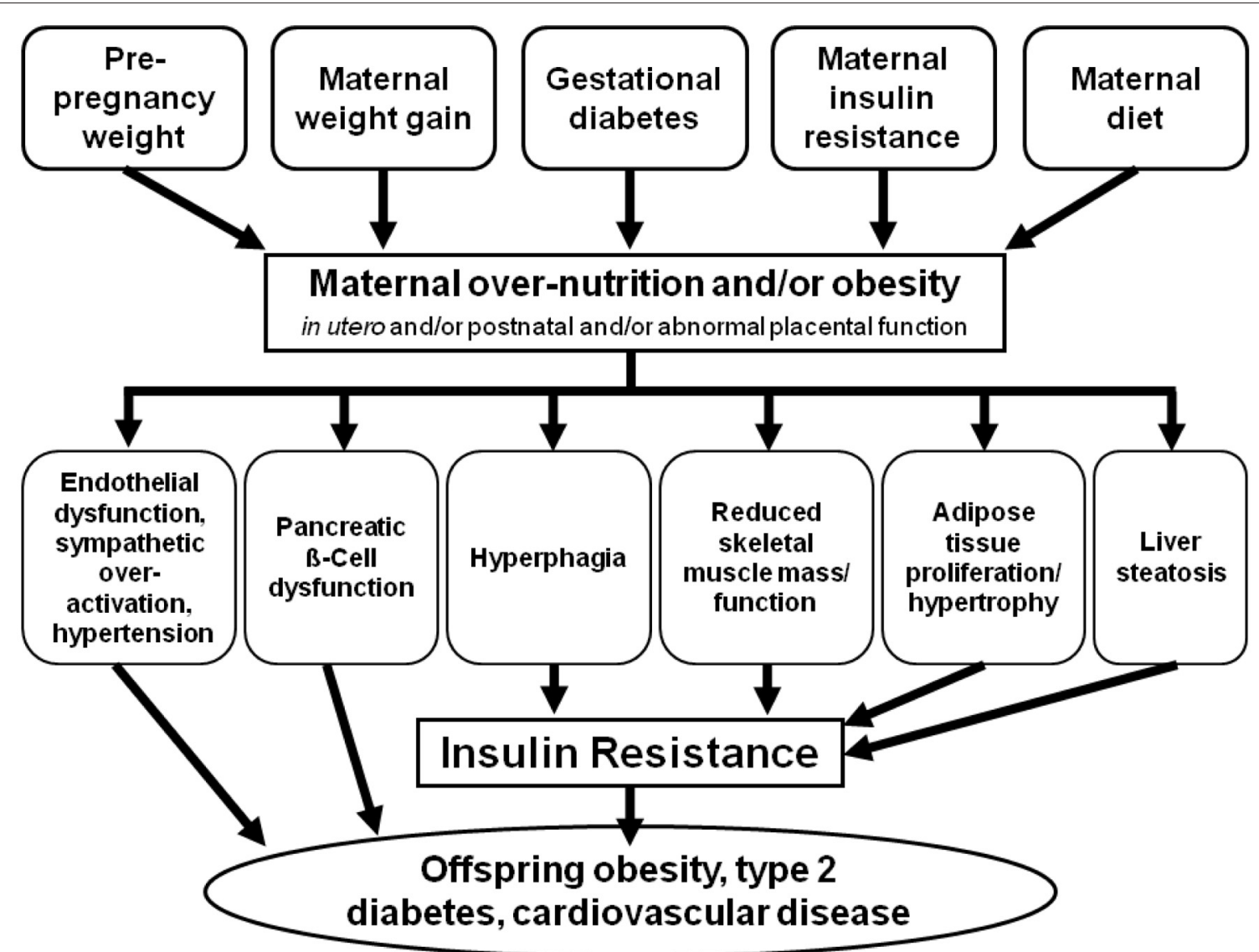

FIGURE 1 | Common mechanistic pathways of developmental programming as a result of maternal over-nutrition and obesity.

these underlying mechanisms and the resulting phenotype of the offspring.

\section{DEVELOPMENT OF THE ENDOCRINE PANCREAS EMBRYONIC DEVELOPMENT OF THE PANCREAS}

Gastrulation is a key stage in early embryonic development. Inward migration of cells at or near the surface of the embryo reorganizes the single layered blastula into a three layered structure composed of the ectoderm, mesoderm and endoderm germ layers. Each layer gives rise to specific tissues and organs in the developing embryo. The pancreas and other gastrointestinal organs are derived from the endoderm.

The pancreas is formed in the uterus from the fusion of two separate pancreatic ducts, the dorsal and ventral. The dorsal pancreatic bud first appears at approximately embryonic day 9.5 (E9.5) in the mouse (Figure 2) [day 25 of gestation in humans (Piper et al., 2002)], as a diverticulum from the dorsal aspect in the primitive gut endoderm, in the area that will become the duodenum, a short distance above the hepatic diverticulum (Wessells and Cohen, 1967). Shortly after, the ventral pancreatic bud appears as a diverticulum from the primitive bile duct. By E11.5 in the mouse the two buds grow rapidly sending finger-like epithelial protrusions into the surrounding mesenchyme leading to the formation of highly branched structures (Zhou et al., 2007; Figure 2).
The dorsal duct grows upward and backward into the dorsal mesogastrium, forms a part of the head and uncinate process and the whole of the body and tail of the pancreas; while the ventral duct forms the remainder of the head and uncinate process of the pancreas (Gittes, 2009). The dorsal duct drains the major portion of the embryonic pancreas into the duodenum and the ventral duct drains only a small part into the common bile duct. By embryonic day 16-17 (E16-17) in the mouse the ventral pancreatic bud and the dorsal pancreatic bud fuse and establish communication between the two ducts (Pictet and Rutter, 1972; Sander and German, 1997). At this time the region between the duodenum and the point of fusion undergoes little, or no, enlargement while the pancreatic duct increases in size and forms a highly branched structure that forms the adult pancreatic duct (Jorgensen et al., 2007).

All islet cell types are believed to be derived from one common progenitor cell (Yamaoka and Itakura, 1999) located at the tips of the branching structures (Zhou et al., 2007). In the mouse, endocrine cells are formed continuously from E9.5 until birth, with a major burst in $\beta$-cell generation between E13.5 and E16.5 (Ahnfelt-Ronne et al., 2012). Before distinct cell types form, insulin and glucagon, pancreatic polypeptide and amylase mRNA are expressed at embryonic days E9.5, E10.5, and E12.5 respectively (Herrera et al., 1991; Gittes and Rutter, 1992; Deltour et al., 1993). Acini and ductal cells become apparent as histologically 


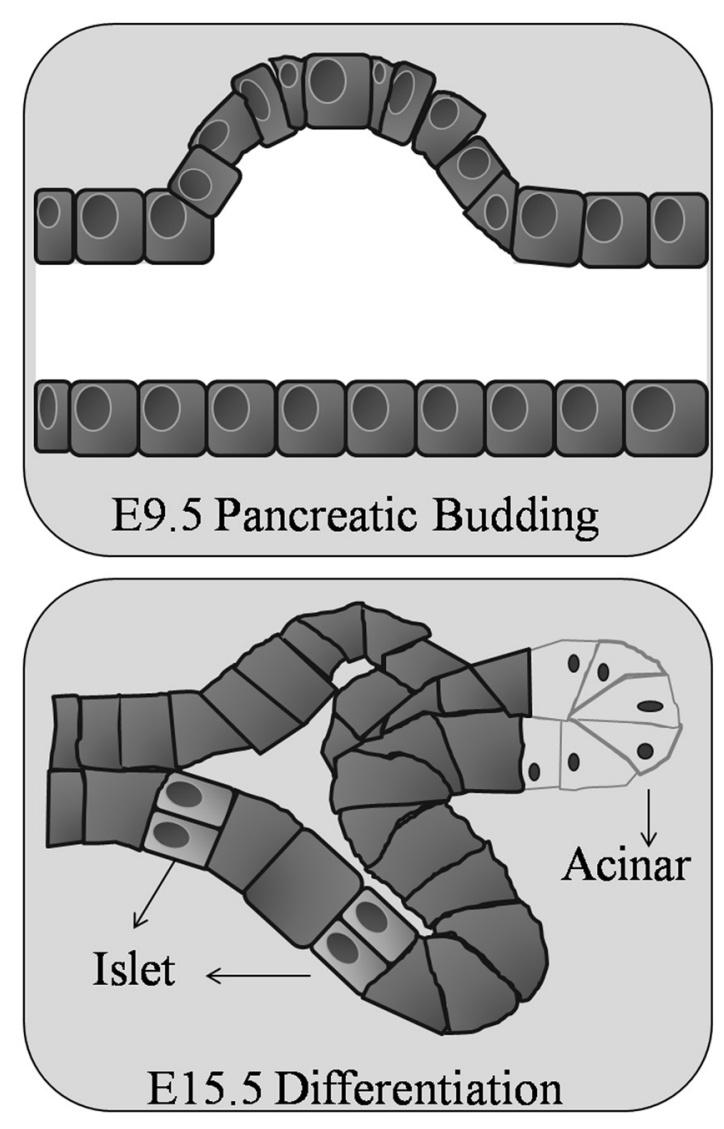

FIGURE 2 | Organogenesis of the murine pancreas. The pancreatic bud begins around day 9 of gestation (E9.5) in the mouse embryo. At E11.5 the pancreatic ductal epithelium grows and branches into the

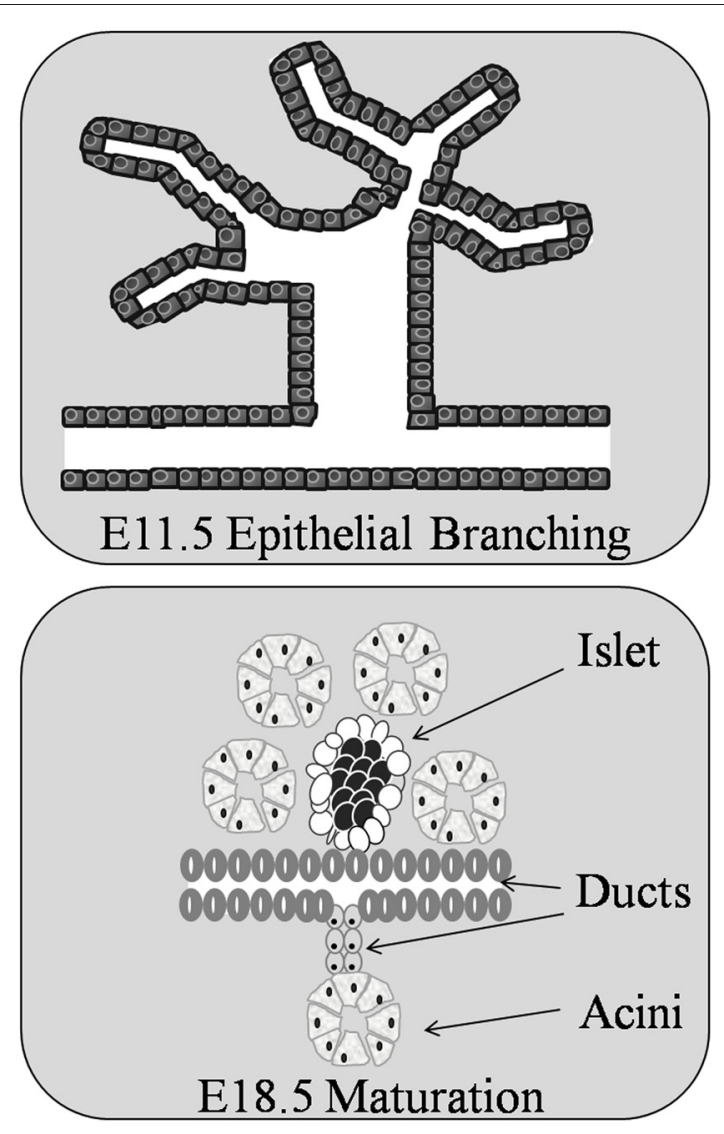

surrounding mesenchyme. The epithelial cells differentiate into exocrine and endocrine cells at E15.5. Ductal, acinar, and islet cells are clearly found by E18.5. distinct structures as early as E15.5 in the mouse; while the islets of Langerhans do not form until around E18.5 (Herrera et al., 1991; Figure 2). After this time, endocrine cell numbers increase rapidly, as a result of ductal epithelial neogenesis rather than multiplication of precursor cells (Deltour et al., 1991; Kaung, 1994). The dorsal primordium is rich in glucagon-containing cells and the ventral primordium is rich in pancreatic polypeptidecontaining cells (Malaisse-Lagae et al., 1979; Stefan et al., 1982) the dorsal lobe, derived from the dorsal duct, possess islets with a $\beta$-cell core surrounded by $\alpha$ - and $\delta$-cells, while the ventral lobe islets have a mantle of PP and $\delta$-cells surrounding the $\beta$-cell core (Tasaka et al., 1989). In the human fetus, endocrine cells begin to bud from the pancreatic duct at around week 10 of gestation. The functional endocrine pancreas continues to develop throughout pregnancy followed by a phase of islet remodeling from late gestation onwards for at least 4 years (Fowden and Hill, 2001; McMillen and Robinson, 2005). Hence, irrespective of species, throughout the process of embryogenesis not all pancreatic islets have the same endocrine cell content.

TRANSCRIPTION FACTORS CONTROLING PANCREATIC DEVELOPMENT The embryological development of the pancreas and the endocrine and exocrine cells is tightly controlled. Throughout these stages of development a network of transcription factors regulate genes that direct cellular differentiation and cell fate (Figure 3). While some transcription factors are only required at specific stages of the formation of the islet cell others are required in multiple stages of endocrine cell development (Murtaugh, 2007).

\section{Transcription factors}

$P d x$-1. Pancreatic duodenal homeobox $1(\mathrm{Pdx}-1)$ is one of the first transcription factors expressed, with gene expression starting as early as E8.5 in the mouse in the foregut endoderm (Offield et al., 1996). All the cells derived from the endoderm have been shown to express Pdx-1 (Gu et al., 2002). Both the ventral and dorsal pancreatic buds express $P d x-1$ at E9.5 (Offield et al., 1996). At approximately E10 expression of $P d x-1 \mathrm{mRNA}$ is then downregulated with expression becoming restricted only to endocrine cells in the pancreas and this is maintained in adult $\beta$-cells (Ohlsson et al., 1993; Ahlgren et al., 1998). Pdx-1 itself is an essential mediator of mesenchymal signaling, necessary for the branching morphogenesis involved in ductal network formation of the pancreas at E10.5 (Ahlgren et al., 1996). Germline knockout studies have shown that while knockdown of $P d x-1$ prior to E10.5 has no effect on pancreatic developmental processes (Wescott et al., 2009), the targeted pancreatic deletion at E10.5 or later results in pancreatic agenesis (Ahlgren et al., 1996; 


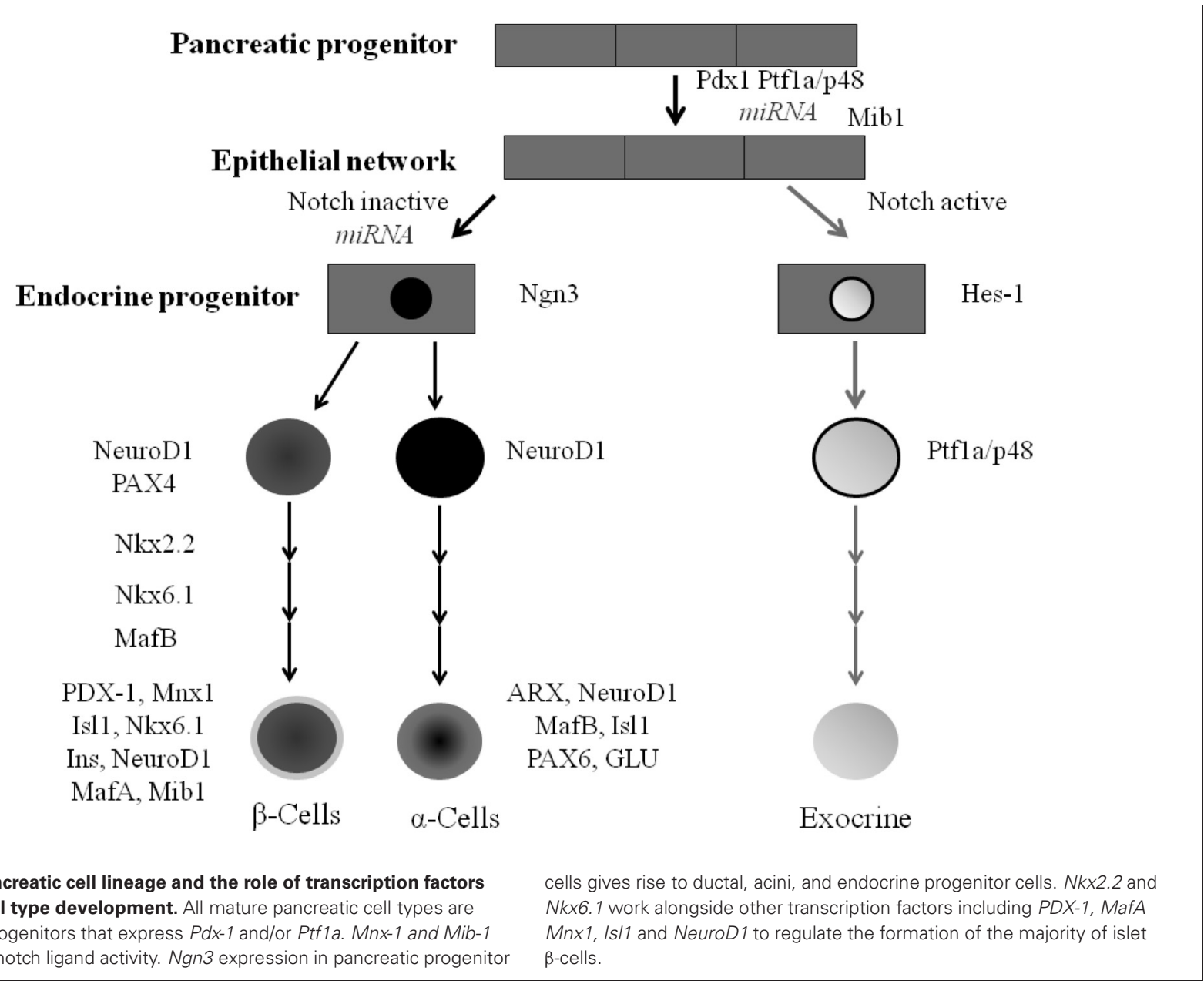

Offield et al., 1996). $P d x-1$ contains three principal transcription initiation sites (Sharma et al., 1996) and in the $\beta$-cell each of these sites may be activated by the binding of a specific set of transcription factors (Melloul et al., 2002); FOXA2, HNF6, PTF1a, MNX-1, MAFA, HNF, SP1/3, USF1/2 and PDX-1 itself (Harrison et al., 1999; Melloul et al., 2002; Jacquemin et al., 2003; Gao et al., 2008; Vanhoose et al., 2008).

Interestingly, reduced expression of the $P D X-1$ gene within the human pancreas has been linked with type 2 diabetes, a rare autosomal dominant form of type 2 diabetes called maturity onset diabetes of the young (MODY4) and pancreatic agenesis (Lin and Vuguin, 2012).

Ptf1a/p48. Ptfla (pancreas specific transcription factor $1 \mathrm{a} / \mathrm{p} 48$ ) is a basic helix-loop-helix (bHLH) transcription factor (Beres et al., 2006). It was first identified as a subunit of the trimeric PTF1 transcription factor complex, and has been found to be crucial for the regulation of exocrine gene transcription (Ohlsson et al., 1993; Krapp et al., 1996). Endodermal expression of Ptfla/p48 is pancreas specific throughout development; being expressed in endocrine, exocrine and ductal cell types (Kawaguchi et al., 2002). PTF1a protein has been detected as early as E8-8.75 in the ventral and dorsal pancreatic ducts (Hald et al., 2008) but by E13.5 expression becomes restricted to acinar precursor cells
(Kawaguchi et al., 2002). In adult rodents, PTF1a/p48 transcription factor protein is expressed in acinar tissue and induces amylase and elastase gene expression.

While a deficiency in PTF1a/p48 protein does not inhibit the initial formation of the pancreas it does cause a complete lack of acinar cell development (Krapp et al., 1998; Kawaguchi et al., 2002). Cell lineage studies have shown that this is through cells adopting an intestinal fate rather than becoming cells within the ventral pancreas (Kawaguchi et al., 2002). Defects in the human PTF1a protein are associated with permanent neonatal diabetes mellitus (Masui et al., 2007). It has recently been suggested that Ptfla-mediated control of Delta-like ligand 1 (Dll1) expression is crucial for Notch-mediated control of early pancreas development (Ahnfelt-Ronne et al., 2012). The Ptfla activation of Dll1 within multipotent progenitor cells (MPC) stimulates proliferation and pancreas growth by maintenance of HES1 (hairy and enhancer of split 1) expression and PTF1a protein levels (Ahnfelt-Ronne et al., 2012).

\section{Endocrine lineage specification}

Differentiation of the cells into each endocrine cell type found within the islet of Langerhans begins at specific time points during embryogenesis. For $\alpha$-cells this is E9.5, for $\beta$-cells E10.5, for $\delta$-cells at E14.5 and lastly PP cells at E18.5. The critical window 
of differentiation of endocrine cells in humans is from weeks 7 to 23 of gestation (Lin and Vuguin, 2012). Glucagon-producing $\alpha$ cells are found at week 7 , followed by insulin-producing $\beta$-cells, somatostatin-producing $\delta$-cells and pancreatic polypeptide PP cells at weeks 8-10 gestation (Lin and Vuguin, 2012). Importantly, the processes that control the development of each cell type are governed by a complex signaling cascade.

Notch cell signaling. The notch cell signaling pathway is a wellconserved signaling pathway that regulates cell fate determination during embryonic development as well as the maintenance of tissue homeostasis during adult life (Bigas and Espinosa, 2012). During development Notch signaling must be regulated to balance the expansion of the progenitor pool with the differentiation of mature cell types (Greenwood et al., 2007), with genetic perturbations of this pathway resulting in a change in pancreatic cell fate (Apelqvist et al., 1999). Notch-mediated signaling ensures the appropriate maintenance of the progenitor cell population through the activation of the bHLH factor Hes1 (Jensen et al., 2000). Loss-of-function experiments have shown that Notch signaling promotes pancreatic progenitor cell self-renewal and/or exocrine lineage commitment (Murtaugh et al., 2003). A reduction in Notch signaling increases the expression of the proendocrine gene $\mathrm{Ngn3}$, promoting an endocrine fate; while those cells exposed to Notch signaling express Hes-1 and p48 mRNA and adopt an exocrine fate (Apelqvist et al., 1999).

Ngn3. Neurogenin 3 (NGN3) is one of the most important transcription factors for endocrine development. All endocrine cell types are derived from progenitor cells expressing the $\mathrm{Ngn} 3$ gene (Gu et al., 2002). The bHLH transcription factor is expressed in two distinct waves (Villasenor et al., 2008). The first phase of Ngn3 expression begins in murine pancreatic progenitor cells at E8.59 resulting in glucagon producing cells, while the second begins at E12 with expression peaking at E15.5 corresponding with endocrine cell differentiation (Gradwohl et al., 2000; Schwitzgebel et al., 2000). Ngn3 null animals are born without islets, and lack all endocrine cell types, develop type 1 diabetes and die 1-3 days after birth (Gradwohl et al., 2000). Ngn3 has been associated with several downstream factors involved in endocrine differentiation and cell subtype specification and maintenance, including Nkx2.2, Nkx6.1, Pax4 Isl1, b2/NeuroD1, Pax6 and Pdx-1 (Huang et al., 2000; Smith et al., 2003; Collombat et al., 2005).

Pax4-Arx. The paired box containing gene 4 (Pax4) mRNA is first detected at E9.5 and is transiently expressed in all endocrine progenitors during pancreatic development, being downregulated shortly after birth (Lin and Vuguin, 2012). Pax4 is expressed downstream of $\mathrm{Ngn3}$, with expression being lost in $\mathrm{Ngn3}$ null mice but not vice versa (Gradwohl et al., 2000; Wang et al., 2004). Pax4 activity appears essential for the appropriate initiation of $\beta$-cell differentiation (Collombat et al., 2005). In the absence of Pax4, $\beta$ - and $\delta$ - cells fail to develop and more $\alpha$ - cells are observed (Collombat et al., 2003, 2005; Sosa-Pineda, 2004). The loss of Pax4 prevents the expression of $P d x-1, H B 9$ and insulin mRNA in $\beta$-cell precursors (Wang et al., 2004). PAX4 has an opposing action to the transcription factor aristaless-related homeobox gene (ARX) (Collombat et al., 2003). Arx gene expression begins at E9.5 during mouse pancreatic development and persists into mature $\alpha$-cells (Collombat et al., 2003). Arx null mice lack $\alpha$-cells despite having no changes in total islet cell number (Collombat et al., 2005). Therefore, it is the balance of Pax4 and Arx that is crucial for cell fate determination of both $\alpha$ - and $\beta$ - cells within the islet (Collombat et al., 2005).

$N k x$. Members of the NK homeodomain transcription factor family are critical regulators of organ development (Stanfel et al., 2005). Of these, $N k \times 2.2$ and $N k \times 6.1$ are involved in endocrine cell lineage and are likely to be the most important during pancreatic development.

Nkx2.2. NKX2.2 is able to bind to both the insulin and Pax4 promoters (Cissell et al., 2003). The $N k \times 2.2$ gene is initially dorsally expressed with $P d x-1$ at E8.75 and ventrally at E9.5 (Jorgensen et al., 2007). However, by E15.5 its expression becomes restricted to only endocrine cells (Sussel et al., 1998). Nkx2.2 deficiency results in a reduction of $\alpha$ - and PP-cells, and the complete loss of $\beta$-cells (Sussel et al., 1998) and in the absence of $N k x 2.2, \beta$-cells fail to activate insulin gene transcription and lack $N k x 6.1$, suggesting that $N k \times 2.2$ is essential for the specification of the mature $\beta$-cell phenotype (Sussel et al., 1998).

Nkx6.1. Nkx6.1 pancreatic gene expression is similar to that of $N k x 2.2$. In mouse models $N k x 6.1$ is expressed in the prospective ventral pancreas domain at E8.75. By E9.0 Nkx6.1 expression switches from the ventral domain to the dorsal domain until E10.5, when ventral expression of $N k x 6.1$ reappears (Jorgensen et al., 2007) and then by E11.5, its expression becomes restricted to the central epithelium (Jorgensen et al., 2007). In adult murine islets, $N k x 6.1$ expression is restricted to $\beta$-cells (Jensen et al., 1996) where it suppresses glucagon expression and modulates glucose stimulated insulin secretion (Schisler et al., 2005). Nkx6.1 acts downstream of $N k x 2.2$ (Sussel et al., 1998) Not only do $N k x 2.2$ single mutant animals lack expression of $N k x 6.1$ within the $\beta$-cell (Sussel et al., 1998) but the Nkx6.1 promoter contains a conserved binding site for $N k x 2.2$ (Sander et al., 2000). In fact, Nkx6.1 deficiency does not affect early pancreas development, but it does result in compromised $\beta$-cell development (Sander et al., 2000) and mutant animals lacking both $N k x 2.2 / N k x 6.1$ have a phenotype identical to that of $N k \times 2.2$ knockout animals (Sander et al., 2000).

\section{Maintenance of $\beta$-cell identity}

NeuroD1/Beta2. NeuroD1/Beta2, a bHLH, is first expressed in mouse pancreatic cells from E9.5 (Naya et al., 1997). By E12.5, NeuroD1/Beta2 mRNA is found in both dorsal and ventral pancreatic buds and from E17.5 gene and protein expression is restricted to small clusters of endocrine cells and is rarely detected in ductal epithelial cells (Chu et al., 2001). In adult islets, NeuroD1/Beta2 is expressed in all endocrine cells of the islet, although its function still remains unknown. While it is believed that NeuroD1/Beta2 plays a role in regulating insulin (Sharma et al., 1999) and glucagon mRNA expression, mice lacking NeuroD1/Beta2 are still able to produce functional insulin and glucagon (Chu et al., 2001). 
Large Maf transcription factors. The Maf family of transcription factors belong to the basic leucine-zipper (bZIP) family that have been associated with the regulation of a number of differentiation processes (Hang and Stein, 2011). The Maf family is divided into two groups (small and large) based on their molecular size (Hang and Stein, 2011). The large Maf proteins MAFA, MAFB, c-MAF and NRL contain a transactivation domain in the $\mathrm{N}$-terminal region and are key regulators of cellular differentiation (Yang and Cvekl, 2007; Hang and Stein, 2011). In adult islets, MAFA, MAFB, and c-MAF are expressed unlike NRL (Matsuoka et al., 2003), supporting a role for NRL in islet cell development.

MafA. MafA gene expression starts at E13.5 and continues throughout adulthood in the mouse (Matsuoka et al., 2003). MafA knockout mice display no changes in pancreas development, but the mice do go on to develop glucose intolerance and type 2 diabetes as a result of reduced $\beta$-cell mass and increased $\beta$-cell apoptosis (Zhang et al., 2005). Furthermore, MAFA binds to the insulin promoter and through its interaction with PDX-1 and NEUROD1, activates insulin gene transcription (Olbrot et al., 2002; Aramata et al., 2005).

$M a f B$. In the adult mouse pancreas $M a f B$ is expressed within the islet $\alpha$-cells where it regulates glucagon gene expression (Artner et al., 2006, 2007). Expression of MafB mRNA within the mouse pancreas begins as early as E10.5 in glucagon-positive cells, before expression in islet positive cells at E12.5 (Artner et al., 2006). MafB becomes progressively restricted to $\alpha$-cells postnatally through the downregulation of its expression in $\beta$-cells in the first 2 weeks after birth and its expression is undetectable in these cells 3 weeks after birth (Artner et al., 2007). MAFB plays a pivotal role in the development and differentiation of $\alpha$ - and $\beta$-cells during pancreatogenesis by directly affecting the transcription of specific genes present in $\alpha$ - or $\beta$-cells as opposed to genes which are more ubiquitously expressed in other islet cell types (e.g., Pax6, Isl1 and NeuroD1) (Artner et al., 2007).

Mib-1. Mind bomb 1 (Mib-1) encodes an E3 ubiquitin ligase essential for Notch ligand activity (Itoh et al., 2003) that is required for correct proximodistal patterning in the developing pancreas as well as in $\beta$-cell formation (Horn et al., 2012). Endodermal-specific inactivation of Mib-1 causes the proximal cells of the developing pancreas to adopt a distal fate resulting in a reduction in $\beta$-cells (Horn et al., 2012).

Mnx-1. The homeodomain transcription factor MNX1 (HB9) plays a key role in pancreatic development and function (Harrison et al., 1999; Li et al., 1999; Dalgin and Prince, 2012). Murine Mnx-1 gene expression begins at E8 (Lin and Vuguin, 2012). Work in zebrafish suggests that $M n x-1$ may suppress $\alpha$-cell fate in $\beta$-cell precursors (Dalgin and Prince, 2012). Furthermore, $M n x-1$ knockout mice fail to develop the dorsal lobe of the pancreas with the remnant pancreas having smaller islets of Langerhans with reduced $\beta$-cell numbers expressing low levels of Glut2 and Nkx6.1 (Harrison et al., 1999).

$\mathbf{L} \boldsymbol{b l - 1 1 / I s l - 1 . ~ T h e ~ t r a n s c r i p t i o n a l ~ r e g u l a t o r ~ I s l e t - 1 ~ ( I s l - 1 ) ~ g e n e ~ i s ~}$ expressed in the developing mouse pancreas at E8-8.5 (Lin and
Vuguin, 2012) but is later restricted only to the endocrine cells of adult islets, where it is involved in the maturation, proliferation and survival of the second wave of islet cells (Du et al., 2009). Isl-1 directly regulates MafA, a potent regulator of the insulin gene and $\beta$-cell function (Du et al., 2009). Isl-1 deficient animals fail to develop functional $\beta$-cells, and have a reduced ability to expand their endocrine cell mass postnatally and consequently become diabetic (Du et al., 2009). A nonsense mutation of the ISL-1 gene has been found in a case of human type 1 diabetic patient. Activation of Isl-1 is regulated in part by the transcriptional coregulator, LIM domain-binding protein 1 (LBL-1) (Hunter et al., 2013).

\section{Other factors}

microRNAs. microRNAs (miRNAs) are small non-coding RNA molecules $(\sim 19-22 \mathrm{nt})$ that regulate gene expression by binding to complementary sequences in the $3^{\prime} \mathrm{UTR}$ regions of specific mRNAs (Ambros, 2004). One of the first miRNAs to be identified in the $\beta$-cell was miR-375 (Poy et al., 2004). miR-375 is regulated by several transcription factors involved in pancreatic development and function, including HNF6, INSM1, NGN3, NEUROD1, and PDX-1 (Keller et al., 2007), with knockout studies showing that miR-375 is key to pancreatic development (Poy et al., 2009). Since the identification of miR-375, a great number more miRNAs have been implicated in many aspects of pancreatic development including regulating ductal, exocrine, and endocrine development (Lynn et al., 2007). For example miR-18a plays a role in regulating pancreatic progenitors and exocrine cells through the repression of Ptfla expression (Yang et al., 2012).

Cell cycle regulators. Regulators of the cell cycle have been relatively understudied during pancreatic development; Of those studied, p27 is a key regulator in establishing $\beta$-cell mass; during embryogenesis accumulates in terminally differentiated $\beta$-cells where it acts to maintain a quiescent state (Georgia and Bhushan, 2006). Inactivation of p27 during embryogenesis results in an increase in $\beta$-cell mass at birth but interestingly does not affect the postnatal expansion of $\beta$-cell mass (Georgia and Bhushan, 2006).

\section{ISLET GROWTH AND DEVELOPMENT IN NEONATES}

The neonatal period is divided into presuckling, suckling and weaning phases. The presuckling period, which represents postnatal days 1-2, describes the transition between fetal life, where the placenta supplies most of the metabolic needs, and extrauterine life. During this period the islet adapts with alternating feeding and fasting states whilst the total islet mass continues to grow and in fact almost doubles during these 2 days (Freie et al., 1975). Throughout postnatal days $3-14$, the suckling period, $\beta$ cell mass and insulin secretion adapt to the composition of the maternal diet and to the dam's feeding patterns. Following an initial reduction in growth and proliferation for all islet cell types during postnatal days 3-4, during the suckling phase there is rapid growth from days 4-10 (Kaung, 1994). During this phase the rate of islet neogenesis is higher than the rate of islet growth, resulting in a large number of small islets (Ferrand et al., 1995). Throughout the mid-stages of the suckling phase there is an increase in the concentration of a number of pancreatic hormones, followed by decrease from the end of the suckling through 
to weaning. Pancreatic insulin levels are at their highest between postnatal days 7-21 and the levels of glucagon and somatostatin increase considerably from birth reaching a peak between days 4 and 7 (Portha et al., 1974). During the weaning phase, postnatal days 15-22, the whole system is honed to produce a fully developed pancreas. At this time, pancreatic weight doubles every 5-6 days until the end of the weaning phase and subsequently the islet density is reduced (Freie et al., 1975).

\section{ISLET GROWTH AND DEVELOPMENT IN THE ADULT}

There are three main mechanisms involved in the regulation of $\beta$-cell mass in adulthood: i) $\beta$-cell replication, which leads to an expansion in $\beta$-cell number (hyperplasia), ii) $\beta$-cell hypertrophy, which leads to an expansion in individual volume and differentiation and iii) $\beta$-cell apoptosis. These processes and the underlying mechanisms have been extensively reviewed previously (BonnerWeir, 2000). Despite no evidence of spontaneous neogenesis occurring in the adult pancreas, it has now been shown that the neogenesis of islets from ductal cells can be activated by exposure to certain peptides (Bonner-Weir, 2000).

\section{THE EFFECTS OF MATERNAL OBESITY AND A HIGH FAT DIET ON OFFSPRING PANCREATIC DEVELOPMENT}

The developmental programming hypothesis suggests that conditions during key periods of fetal and early neonatal life may impair pancreatic $\beta$-cell development and alter health in adulthood (Zambrano et al., 2006). It is well-established in rodent models that intrauterine growth restriction (IUGR), followed by normal or supranormal nutrition after birth can result in impaired growth of $\beta$-cells, a reduction of $\beta$-cell mass and insulin content (Pinney et al., 2011; Frantz et al., 2012; Martin-Gronert and Ozanne, 2012) and an increased susceptibility to insulin resistance, visceral obesity, type 2 diabetes and other features of the metabolic syndrome in adulthood (Hales and Barker, 1992; Stocker et al., 2005; Sandovici et al., 2011). There are many models used to study IUGR including maternal low protein diet and placental insufficiency models (reviewed, Schwitzgebel et al., 2009; Portha et al., 2011; Tarry-Adkins and Ozanne, 2011), in this review we will focus on the model of maternal obesity.

In the United Kingdom around 50\% of women of childbearing age are either overweight with a body mass index (BMI) of $25-29.9 \mathrm{~kg} / \mathrm{m}^{2}$ or obese (BMI $\geq 30 \mathrm{~kg} / \mathrm{m}^{2}$ ) (Thangaratinam et al., 2012). In $20105 \%$ of the UK maternity population were severely obese (CMACE, 2010). Not only does increased adiposity affect maternal health but there is also increasing evidence that obesity during pregnancy and lactation can have long term effects on the health of the child, increasing susceptibility to type 2 diabetes (McCance et al., 1994; Nelson et al., 2010; Alfaradhi and Ozanne, 2011; Poston, 2012; Rkhzay-Jaf et al., 2012; Yang and Huffman, 2013).

Over the last decade evidence has grown that exposure of rats to palatable and high-saturated-fat diets in-utero and/or during lactation also compromises $\beta$-cell development and function in neonatal and weanling offspring (Cerf, 2011; Cerf et al., 2012). A high fat diet (HFD) pre-gestation, during gestation or postnatally will have different effects depending on the exposure time to the diet (Dalgin and Prince, 2012). In the majority of studies, HFD were administered to pregnant and/or lactating rats to programme an adverse metabolic phenotype in the offspring (Cerf, 2010). In neonates, exposure to a maternal HFD throughout gestation was observed to have an adverse effect on $\beta$-cell development which resulted in hyperglycemia (Cerf et al., 2005). Similarly offspring of dams fed a HFD through gestation alone showed altered neonatal islet morphology with increased $\alpha$-cell number and size and with an opposite effect on the $\beta$-cell (Cerf et al., 2009). In contrast, offspring of obese dams fed an obesogenic diet throughout gestation and lactation were hyperinsulinemic at 3 months of age (Samuelsson et al., 2008). This has been associated with an increase in pancreatic insulin content, increased islet number and increased $\beta$-cell mass in early life (Rkhzay-Jaf et al., 2011), which declines with age due to persistent stimulation (Srinivasan et al., 2008). Similar observations were recorded in sheep where, at lambing, reduced offspring $\beta$-cell numbers was associated with an increase in $\beta$-cell apoptosis (Zhang et al., 2011).

Previous studies conducted in the rat low-protein model of IUGR, resulted in a reduction of PDX-1 protein expression (Park et al., 2008) as well as a reduction in mRNA expression of Glut2, Hnf4a, Pdx-1, Rfx6, and Ins (Pinney and Simmons, 2010; Sandovici et al., 2011; Rodriguez-Trejo et al., 2012). Similarly, exposure to a HFD can also alter both the glucose sensing and insulin signaling mechanism of islets. Studies have shown that offspring of obese over-nourished rat dams have a reduction in insulin, glucokinase and GLUT2 protein expression (Kim et al., 1995; Jorns et al., 2002; Cerf et al., 2006), as well as a reduction in PDX-1 protein (Reimer and Ahren, 2002; Cerf et al., 2009). The alterations of these factors by gestational high fat feeding may contribute to the reduction of $\beta$-cell number by similar mechanisms to those seen in maternally undernourished models.

While the mechanisms that govern the adaptation of the $\beta$ cell to their altered in-utero environment are not fully understood it is in part due to epigenetic modifications, including DNA methylation, histone modifications and microRNAs, of which DNA methylation is the most commonly studied. Methyl donors are sourced from the diet and methylation patterns are established during the early development of many organs including the pancreas. Therefore, methyl donor imbalances could alter these epigenetic patterns and increase an individual's susceptibility to metabolic disease in later life (Waterland and Garza, 2002; Sandovici et al., 2011). The many transcription factors that control pancreatic development and endocrine cell fate may be subjected to epigenetic regulation (Avrahami and Kaestner, 2012; Sandovici et al., 2013). Previous studies of the developing pancreas have shown that epigenetic dysregulation brought about by an altered in-utero environment increases the long term susceptibility to type 2 diabetes (Simmons, 2007; Thompson et al., 2010). Park et al demonstrated that the development of type 2 diabetes following IUGR is in part due to epigenetic changes that result in the silencing of $P d x-1$ gene (Park et al., 2008). Due to the commonalities in the phenotypes produced by the various models of developmental programming (Portha et al., 2011), similar abnormal metabolic intrauterine milieu such as a maternal 
HFD may also affect the development of the fetus by permanently modifying gene expression through epigenetic mechanisms.

More recently, a study in rodents has shown that a paternal HFD results in impaired glucose tolerance in his female offspring. By adulthood, these female offspring have impaired $\beta$ - cell function, associated with reduced islet area and the altered expression of 642 pancreatic islet genes many of which have been shown to be involved in calcium, MAPK- and Wnt-signaling pathways, as well as apoptosis and the cell cycle ( $\mathrm{Ng}$ et al., 2010). Given the fact that maintaining dams on a HFD for a single week during pregnancy can impair $\beta$-cell development and function in the weanlings (Cerf et al., 2007) and that a paternal HFD may affect offspring pancreatic islet development, the combined impact of both maternal and paternal diet may produce an exacerbated or different phenotype. Therefore, it is clearly important to understand

\section{REFERENCES}

Ahlgren, U., Jonsson, J., and Edlund, H. (1996). The morphogenesis of the pancreatic mesenchyme is uncoupled from that of the pancreatic epithelium in IPF1/PDX1-deficient mice. Development 122, 1409-1416.

Ahlgren, U., Jonsson, J., Jonsson, L., Simu, K., and Edlund, H. (1998). beta-cell-specific inactivation of the mouse Ipf1/Pdxl gene results in loss of the beta-cell phenotype and maturity onset diabetes. Genes Dev. 12, 1763-1768. doi: 10.1101/gad.12.12.1763

Ahnfelt-Ronne, J., Jorgensen, M. C., Klinck, R., Jensen, J. N., Fuchtbauer, E. M., Deering, T., et al. (2012). Ptfla-mediated control of Dll1 reveals an alternative to the lateral inhibition mechanism. Development 139, 33-45. doi: 10.1242/dev.071761

Alfaradhi, M. Z., and Ozanne, S. E. (2011). Developmental programming in response to maternal overnutrition. Front. Genet. 2:27. doi: 10.3389/fgene.2011.00027

Ambros, V. (2004). The functions of animal microRNAs. Nature 431, 350-355. doi: 10.1038/nature02871

Apelqvist, A., Li, H., Sommer, L., Beatus, P., Anderson, D. J., Honjo, T., et al. (1999). Notch signalling controls pancreatic cell differentiation. Nature 400, 877-881. doi: $10.1038 / 23716$

Aramata, S., Han, S. I., Yasuda, K., and Kataoka, K. (2005). Synergistic activation of the insulin gene promoter by the beta-cell enriched transcription factors MafA, Beta2, and Pdx1. Biochim. Biophys. Acta 1730, 41-46. doi: 10.1016/j.bbaexp.2005.05.009

Artner, I., Blanchi, B., Raum, J. C., Guo, M., Kaneko, T., Cordes, S., et al. (2007). MafB is required for islet beta cell maturation. Proc. Natl.
Acad. Sci. U.S.A. 104, 3853-3858. doi: 10.1073/pnas.0700013104

Artner, I., Le Lay, J., Hang, Y., Elghazi, L., Schisler, J. C., Henderson, E., et al. (2006). MafB: an activator of the glucagon gene expressed in developing islet alpha- and beta-cells. Diabetes 55, 297-304. doi: 10.2337/ diabetes.55.02.06.db05-0946

Avrahami, D., and Kaestner, K. H. (2012). Epigenetic regulation of pancreas development and function. Semin. Cell Dev. Biol. 23, 693-700. doi: 10.1016/j.semcdb.2012.06.002

Beres, T. M., Masui, T., Swift, G. H., Shi, L., Henke, R. M., and MacDonald, R. J. (2006). PTF1 is an organspecific and Notch-independent basic helix-loop-helix complex containing the mammalian Suppressor of Hairless (RBP-J) or its paralogue, RBP-L. Mol. Cell. Biol. 26, 117-130. doi: $\quad$ 10.1128/MCB.26.1.117-130. 2006

Bigas, A., and Espinosa, L. (2012). Hematopoietic stem cells: to be or Notch to be. Blood 119, 3226-3235. doi: 10.1182/blood-2011-10355826

Bonner-Weir, S. (2000). Islet growth and development in the adult. J. Mol. Endocrinol. 24, 297-302. doi: 10.1677/jme.0.0240297

Bonner-Weir, S., and Orci, L. (1982). New perspectives on the microvasin the rat. Diabetes 31, 883-889. doi: $10.2337 /$ diabetes.31.10.883

Centre for Maternal and Child Enquiries (CMACE). (2010). Maternal obesity in the UK: Findings from a national project. London: CMACE

Cerf, M. E. (2010). High fat programming of beta-cell failure. $A d v$. culature of the islets of Langerhans

the potential impact of maternal and paternal obesity on the offspring.

\section{CONCLUSION}

Recent studies in both animal models and in humans have highlighted the impact of both increased maternal and paternal obesity and over-nutrition on the in-utero and postnatal environment and the consequences of developmental programming on an infant's susceptibility to metabolic disorders in later life. It is therefore essential that we understand these programming signals during the key developmental periods of organs such as the pancreas. The identification and a greater understanding of such programming mechanisms will inform the design of successful maternal intervention strategies, removing the risk of altered organ development and rescue the offspring from developing a detrimental phenotype in later life.

Exp. Med. Biol. 654, 77-89. doi: 10.1007/978-90-481-3271-3_5

Cerf, M. E. (2011). Parental high-fat programming of offspring development, health and beta-cells. Islets 3, 118-120. doi: 10.4161/isl.3.3.15420

Cerf, M. E., Chapman, C. S., and Louw, J. (2012). High-fat programming of hyperglycemia, hyperinsulinemia, insulin resistance, hyperleptinemia, and altered islet architecture in 3-month-old wistar rats. ISRN Endocrinol. 2012, 627270. doi: 10.5402/2012/627270

Cerf, M. E., Chapman, C. S., Muller, C. J., and Louw, J. (2009). Gestational high-fat programming impairs insulin release and reduces $\mathrm{Pdx}-1$ and glucokinase immunoreactivity in neonatal Wistar rats. Metabolism 58, 1787-1792. doi: 10.1016/j.metabol.2009.06.007

Cerf, M. E., Muller, C. J., Du Toit, D. F., Louw, J., and Wolfe-Coote, S. A. (2006). Hyperglycaemia and reduced glucokinase expression in weanling offspring from dams maintained on a high-fat diet. Br. J. Nutr. 95, 391-396. doi: 10.1079/BJN20051632

Cerf, M. E., Williams, K., Chapman, C. S., and Louw, J. (2007). Compromised beta-cell development and beta-cell dysfunction in weanling offspring from dams maintained on a highfat diet during gestation. Pancreas 34, 347-353. doi: 10.1097/MPA.0b013e31802ee9ae

Cerf, M. E., Williams, K., Nkomo, X. I., Muller, C. J., Du Toit, D. F., Louw, J., et al. (2005). Islet cell response in the neonatal rat after exposure to a high-fat diet during pregnancy. Am. J. Physiol. Regul. Integr. Comp. Physiol. 288, R1122-R1128. doi: 10.1152/ajpregu.00335.2004
Chu, K., Nemoz-Gaillard, E., and Tsai, M. J. (2001). BETA2 and pancreatic islet development. Recent Prog. Horm. Res. 56, 23-46. doi: 10.1210/rp.56.1.23

Cissell, M. A., Zhao, L., Sussel, L., Henderson, E., and Stein, R. (2003). Transcription factor occupancy of the insulin gene in vivo. Evidence for direct regulation by Nkx2.2. J. Biol. Chem. 278, 751-756. doi: 10.1074/ jbc.M205905200

Collombat, P., Hecksher-Sorensen, J., Broccoli, V., Krull, J., Ponte, I., Mundiger, T., et al. (2005). The simultaneous loss of Arx and Pax4 genes promotes a somatostatinproducing cell fate specification at the expense of the alpha- and beta-cell lineages in the mouse endocrine pancreas. Development 132, 2969-2980. doi: 10.1242/dev. 01870

Collombat, P., Mansouri, A., HecksherSorensen, J., Serup, P., Krull, J., Gradwohl, G., et al. (2003). Opposing actions of Arx and Pax4 in endocrine pancreas development. Genes Dev. 17, 2591-2603. doi: 10.1101/gad. 269003

Dalgin, G., and Prince, V. E. (2012). Mnxl: a gatekeeper of beta cell fate. Islets 4, 320-322. doi: 10.4161/isl. 21984

Deltour, L., Leduque, P., Blume, N., Madsen, O., Dubois, P., Jami, J., et al. (1993). Differential expression of the two nonallelic proinsulin genes in the developing mouse embryo. Proc. Natl. Acad. Sci. U.S.A. 90, 527-531. doi: 10.1073/pnas.90. 2.527

Deltour, L., Leduque, P., Paldi, A., Ripoche, M., Dubois, P., and Jami, J. (1991). Polyclonal origin of pancreatic islets in aggregation 
mouse chimaeras. Development $112,1115-1121$.

Du, A., Hunter, C. S., Murray, J., Noble, D., Cai, C. L., Evans, S. M., et al. (2009). Islet-1 is required for the maturation, proliferation, and survival of the endocrine pancreas. Diabetes 58, 2059-2069. doi: 10.2337/db08-0987

Ferrand, N., Astesano, A., Phan, H. H., Lelong, C., and Rosselin, G. (1995). Dynamics of pancreatic cell growth and differentiation during diabetes reversion in STZ-treated newborn rats. Am. J. Physiol. Cell Physiol. 269, C1250-C1264.

Fowden, A. L., and Hill, D. J. (2001). Intra-uterine programming of the endocrine pancreas. Br. Med. Bull. 60, 123-142. doi: 10.1093/bmb/60. 1.123

Frantz, E. D., Peixoto-Silva, N., and Pinheiro-Mulder, A. (2012). Endocrine pancreas development: effects of metabolic and intergenerational programming caused by a protein-restricted diet. Pancreas 41, 1-9. doi: 10.1097/MPA. 0b013e3182236320

Freie, H., Pasma, A., and Bouman, P. (1975). Quantitative analysis of pancreatic islet development and insulin storage in the foetal and newborn rat. Acta Endocrinol. 80, 657-666.

Gao, N., LeLay, J., Vatamaniuk, M. Z., Rieck, S., Friedman, J. R., and Kaestner, K. H. (2008). Dynamic regulation of Pdx1 enhancers by Foxa1 and Foxa2 is essential for pancreas development. Genes Dev. 22, 3435-3448. doi: 10.1101/gad. 1752608

Georgia, S., and Bhushan, A. (2006). p27 Regulates the transition of betacells from quiescence to proliferation. Diabetes 55, 2950-2956. doi: 10.2337/db06-0249

Gittes, G., and Rutter, W. (1992). Onset of cell-specific gene expression in the developing mouse pancreas. Proc. Natl. Acad. Sci. U.S.A. 89, 1128-1132. doi: 10.1073/pnas.89.3.1128

Gittes, G. K. (2009). Developmental biology of the pancreas: a comprehensive review. Dev. Biol. 326, 4-35. doi: 10.1016/j.ydbio.2008.10.024

Gradwohl, G., Dierich, A., LeMeur, M., and Guillemot, F. (2000). neurogenin 3 is required for the development of the four endocrine cell lineages of the pancreas. Proc. Natl. Acad. Sci. U.S.A. 97, 1607-1611. doi: 10.1073/pnas.97.4.1607

Greenwood, A. L., Li, S., Jones, K., and Melton, D. A. (2007). Notch signaling reveals developmental plasticity of Pax4(+) pancreatic endocrine progenitors and shunts them to a duct fate. Mech. Dev. 124, 97-107. doi: 10.1016/j.mod.2006.11.002

Gu, G., Dubauskaite, J., and Melton, D. A. (2002). Direct evidence for the pancreatic lineage: NGN3+ cells are islet progenitors and are distinct from duct progenitors. Development 129, 2447-2457.

Hald, J., Sprinkel, A. E., Ray, M., Serup, P., Wright, C., and Madsen, O. D. (2008). Generation and characterization of Ptfla antiserum and localization of Ptfla in relation to Nkx6.1 and Pdxl during the earliest stages of mouse pancreas development. J. Histochem. Cytochem. 56, 587-595. doi: 10.1369/jhc.2008.950675

Hales, C. N., and Barker, D. J. (1992). Type 2 (non-insulin-dependent) diabetes mellitus: the thrifty phenotype hypothesis. Diabetologia 35 , 595-601. doi: 10.1007/BF00400248

Hang, Y., and Stein, R. (2011). MafA and MafB activity in pancreatic beta cells. Trends Endocrinol. Metab. 22, 364-373. doi: 10.1016/j.tem.2011.05.003

Harrison, K. A., Thaler, J., Pfaff, S. L., Gu, H., and Kehrl, J. H. (1999). Pancreas dorsal lobe agenesis and abnormal islets of Langerhans in Hlxb9-deficient mice. Nat. Genet. $23,71-75$.

Herrera, P., Huarte, J., Sanvito, F., Meda, P., Orci, L., and Vassalli, J. (1991). Embryogenesis of the murine endocrine pancreas; early expression of pancreatic polypeptide gene. Development 113, 1257-1265.

Horn, S., Kobberup, S., Jørgensen, M. C., Kalisz, M., Klein, T., Kageyama, R., et al. (2012). Mind bomb 1 is required for pancreatic $\beta$ cell formation. Proc. Natl. Acad. Sci. U.S.A. 109, 7356-7361. doi: 10.1073/pnas.1203605109

Huang, H. P., Liu, M., El-Hodiri, H. M., Chu, K., Jamrich, M., and Tsai, M. J. (2000). Regulation of the pancreatic islet-specific gene BETA2 (neuroD) by neurogenin 3. Mol. Cell. Biol. 20, 3292-3307. doi: 10.1128/MCB.20.9.3292-3307. 2000

Hunter, C. S., Dixit, S., Cohen, T., Ediger, B., Wilcox, C., Ferreira, M., et al. (2013). Islet $\alpha$-, $\beta$-, and $\delta$ cell development is controlled by the Ldb1 coregulator, acting primarily with the islet-1 transcription factor. Diabetes 62, 875-886.

Itoh, M., Kim, C. H., Palardy, G., Oda, T., Jiang, Y. J., Maust, D., et al. (2003). Mind bomb is a ubiquitin ligase that is essential for efficient activation of Notch signaling by Delta. Dev. Cell 4, 67-82. doi: 10.1016/S1534-5807(02)00409-4

Jacquemin, P., Lemaigre, F. P., and Rousseau, G. G. (2003). The Onecut transcription factor HNF-6 (OC-1) is required for timely specification of the pancreas and acts upstream of Pdx-1 in the specification cascade. Dev. Biol. 258, 105-116. doi: $\quad 10.1016 / S 0012-1606(03)$ 00115-5

Jensen, J., Pedersen, E. E., Galante, P., Hald, J., Heller, R. S., Ishibashi, M., et al. (2000). Control of endodermal endocrine development by Hes-1. Nat. Genet. 24, 36-44. doi: 10.1038/71657

Jensen, J., Serup, P., Karlsen, C., Nielsen, T. F., and Madsen, O. D. (1996). mRNA profiling of rat islet tumors reveals nkx 6.1 as a beta-cell-specific homeodomain transcription factor. J. Biol. Chem. 271, 18749-18758. doi: 10.1074/jbc.271.31.18749

Jorgensen, M. C., Ahnfelt-Ronne, J., Hald, J., Madsen, O. D., Serup, P., and Hecksher-Sorensen, J. (2007). An illustrated review of early pancreas development in the mouse. Endocr. Rev. 28, 685-705. doi: 10.1210/er.2007-0016

Jorns, A., Tiedge, M., Ziv, E., Shafrir, E., and Lenzen, S. (2002). Gradual loss of pancreatic beta-cell insulin, glucokinase and GLUT2 glucose transporter immunoreactivities during the time course of nutritionally induced type- 2 diabetes in Psammomys obesus (sand rat). Virchows Arch. 440, 63-69. doi: 10.1007/s004280100490

Kaung, H. (1994). Growth dynamics of pancreatic islet cell populations during fetal and neonatal development of the rat. Dev. Dyn. 200, 163-175. doi: 10.1002/aja.1002000208

Kawaguchi, Y., Cooper, B., Gannon, M., Ray, M., MacDonald, R. J., and Wright, C. V. (2002). The role of the transcriptional regulator Ptfla in converting intestinal to pancreatic progenitors. Nat. Genet. 32, 128-134. doi: 10.1038/ng959

Keller, D. M., McWeeney, S., Arsenlis, A., Drouin, J., Wright, C. V., Wang, H., et al. (2007). Characterization of pancreatic transcription factor Pdx-1 binding sites using promoter microarray and serial analysis of chromatin occupancy. J. Biol. Chem. 282, 32084-32092. doi: 10.1074/jbc.M700899200

Kim, Y., Iwashita, S., Tamura, T., Tokuyama, K., and Suzuki, M. (1995). Effect of high-fat diet on the gene expression of pancreatic GLUT2 and glucokinase in rats. Biochem. Biophys. Res.
Commun. 208, 1092-1098. doi: 10.1006/bbrc. 1995.1446

Krapp, A., Knofler, M., Frutiger, S. Hughes, G. J., Hagenbuchle, O., and Wellauer, P. K. (1996). The p48 DNA-binding subunit of transcription factor PTF1 is a new exocrine pancreas-specific basic helix-loop-helix protein. $E M B O \mathrm{~J}$. 15, 4317-4329.

Krapp, A., Knofler, M., Ledermann, B., Burki, K., Berney, C., Zoerkler, N., et al. (1998). The bHLH protein PTF1-p48 is essential for the formation of the exocrine and the correct spatial organization of the endocrine pancreas. Genes Dev. 12, 3752-3763. doi: 10.1101/gad.12.23.3752

Li, H., Arber, S., Jessell, T. M., and Edlund, H. (1999). Selective agenesis of the dorsal pancreas in mice lacking homeobox gene Hlxb9. Nat. Genet. 23, 67-70. doi: $10.1038 / 12669$

Li, M., Sloboda, D. M., and Vickers, M. H. (2011). Maternal obesity and developmental programming of metabolic disorders in offspring: evidence from animal models. Exp. Diabetes Res. 2011， 592408. doi: 10.1155/2011/592408

Lin, C. L., and Vuguin, P. M. (2012). Determinants of pancreatic islet development in mice and men: a focus on the role of transcription factors. Horm. Res. Paediatr. 77 205-213. doi: 10.1159/000337219

Lynn, F. C., Skewes-Cox, P., Kosaka, Y., McManus, M. T., Harfe, B. D., and German, M. S. (2007). MicroRNA expression is required for pancreatic islet cell genesis in the mouse. Diabetes 56, 2938-2945. doi: $10.2337 / \mathrm{db} 07-0175$

Malaisse-Lagae, F., Stefan, Y., Cox, J., Perrelet, A., and Orci, L. (1979). Identification of a lobe in the adult human pancreas rich in pancreatic polypeptide. Diabetologia 17, 361-365. doi: 10.1007/BF01236270

Martin-Gronert, M. S., and Ozanne, S. E. (2012). Metabolic programming of insulin action and secretion. Diabetes Obes. Metab. 14(Suppl. 3), 29-39. doi: 10.1111/j.1463-1326.2012.01653.x

Masui, T., Long, Q., Beres, T. M., Magnuson, M. A., and MacDonald, R. J. (2007). Early pancreatic development requires the vertebrate Suppressor of Hairless (RBPJ) in the PTF1 bHLH complex. Genes Dev. 21, 2629-2643. doi: 10.1101/gad.1575207

Matsuoka, T. A., Zhao, L., Artner, I., Jarrett, H. W., Friedman, D., Means, A., et al. (2003). Members of the large Maf transcription 
family regulate insulin gene transcription in islet beta cells. Mol. Cell. Biol. 23, 6049-6062. doi: $\quad$ 10.1128/MCB.23.17.60496062.2003

McCance, D. R., Pettitt, D. J., Hanson, R. L., Jacobsson, L. T., Knowler, W. C., and Bennett, P. H. (1994). Birth weight and non-insulin dependent diabetes: thrifty genotype, thrifty phenotype, or surviving small baby genotype. BMJ 308, 942-945. doi: 10.1136/bmj.308. 6934.942

McMillen, I. C., and Robinson, J. S. (2005). Developmental origins of the metabolic syndrome: prediction, plasticity, and programming. Physiol. Rev. 85, 571-633. doi: 10.1152/physrev.00053.2003

Melloul, D., Marshak, S., and Cerasi, E. (2002). Regulation of $\mathrm{pdx}-1$ gene expression. Diabetes 51(Suppl. 3), S320-S325. doi: 10.2337/diabetes.51.2007.S320

Murtaugh, L. C. (2007). Pancreas and beta-cell development: from the actual to the possible. Development 134, 427-438. doi: 10.1242/dev.02770

Murtaugh, L. C., Stanger, B. Z., Kwan, K. M., and Melton, D. A. (2003). Notch signaling controls multiple steps of pancreatic differentiation. Proc. Natl. Acad. Sci. U.S.A. 100, 14920-14925. doi: 10.1073/pnas.2436557100

Naya, F. J., Huang, H. P., Qiu, Y., Mutoh, H., DeMayo, F. J., Leiter, A. B., et al. (1997). Diabetes, defective pancreatic morphogenesis, and abnormal enteroendocrine differentiation in BETA2/neuroD-deficient mice. Genes Dev. 11, 2323-2334. doi: 10.1101/gad.11.18.2323

Nelson, S. M., Matthews, P., and Poston, L. (2010). Maternal metabolism and obesity: modifiable determinants of pregnancy outcome. Hum. Reprod. Update 16, 255-275. doi: 10.1093/humupd/ dmp050

Ng, S.-F., Lin, R. C. Y., Laybutt, D. R., Barres, R., Owens, J. A., and Morris, M. J. (2010). Chronic highfat diet in fathers programs $\beta$ cell dysfunction in female rat offspring. Nature 467, 963-966. doi: 10.1038/nature09491

Offield, M. F., Jetton, T. L., Labosky, P. A., Ray, M., Stein, R. W., Magnuson, M. A., et al. (1996). PDX-1 is required for pancreatic outgrowth and differentiation of the rostral duodenum. Development 122, 983-995.

Ohlsson, H., Karlsson, K., and Edlund, T. (1993). IPF1, a homeodomaincontaining transactivator of the insulin gene. $E M B O$ J. 12, 4251-4259.

Olbrot, M., Rud, J., Moss, L. G., and Sharma, A. (2002). Identification of beta-cell-specific insulin gene transcription factor RIPE3b1 as mammalian MafA. Proc. Natl. Acad. Sci. U.S.A. 99, 6737-6742. doi: 10.1073/pnas.102168499

Paris, M., Tourrel-Cuzin, C., Plachot, C., and Ktorza, A. (2004). Review: pancreatic betacell neogenesis revisited. Exp. Diabesity Res. 5, 111-121. doi: 10.1080/15438600490455079

Park, J. H., Stoffers, D. A., Nicholls, R. D., and Simmons, R. A. (2008). Development of type 2 diabetes following intrauterine growth retardation in rats is associated with progressive epigenetic silencing of Pdx1. J. Clin. Invest. 118, 2316-2324.

Pictet, R., and Rutter, W. J. (1972). "Development of embryonic endocrine pancreas," in Handbook of Physiology, Section 7: Endocrinology, Vol. 1, eds D. F. Steiner, and N. Frenkel (Washington, DC: American Physiological Society), 25-66.

Pinney, S. E., Jaeckle Santos, L. J., Han, Y., Stoffers, D. A., and Simmons, R. A. (2011). Exendin-4 increases histone acetylase activity and reverses epigenetic modifications that silence $\mathrm{Pdx} 1$ in the intrauterine growth retarded rat. Diabetologia 54, 2606-2614. doi: 10.1007/s00125-011-2250-1

Pinney, S. E., and Simmons, R. A. (2010). Epigenetic mechanisms in the development of type 2 diabetes. Trends Endocrinol. Metab. 21, 223-229. doi: 10.1016/j.tem.2009.10.002

Piper, K., Ball, S. G., Turnpenny, L. W., Brickwood, S., Wilson, D. I., and Hanley, N. A. (2002). Beta-cell differentiation during human development does not rely on nestinpositive precursors: implications for stem cell-derived replacement therapy. Diabetologia 45, 1045-1047. doi: 10.1007/s00125-002-0864-Z

Portha, B., Chavey, A., and Movassat, J. (2011). Early-life origins of type 2 diabetes: fetal programming of the beta-cell mass. Exp. Diabetes Res. 2011, 105076

Portha, B., Levacher, C., Picon, L., and Rosselin, G. (1974). Diabetogenic effect of streptozotocin in the rat during the perinatal period. Diabetes 23, 889-895.

Poston, L. (2012). Maternal obesity, gestational weight gain and diet as determinants of offspring long term health. Best Pract. Res. Clin.
Endocrinol. Metab. 26, 627-639. doi: 10.1016/j.beem.2012.03.010

Poy, M. N., Eliasson, L., Krutzfeldt, J., Kuwajima, S., Ma, X., Macdonald, P. E., et al. (2004). A pancreatic isletspecific microRNA regulates insulin secretion. Nature 432, 226-230. doi: 10.1038/nature03076

Poy, M. N., Hausser, J., Trajkovski, M., Braun, M., Collins, S., Rorsman, P., et al. (2009). miR-375 maintains normal pancreatic alpha- and beta-cell mass. Proc. Natl. Acad. Sci. U.S.A. 106, 5813-5818. doi: 10.1073/pnas.0810550106

Reimer, M. K., and Ahren, B. (2002) Altered beta-cell distribution of pdx-1 and GLUT-2 after a short-term challenge with a high-fat diet in C57BL/6J mice. Diabetes 51(Suppl. 1), S138-S143. doi: $\quad 10.2337 /$ diabetes.51.2007. S138

Rkhzay-Jaf, J., O'Dowd, J. F., and Stocker, C. J. (2012). Maternal obesity and the fetal origins of the metabolic syndrome. Curr. Cardiovasc. Risk Rep. 6, 487-495.

Rkhzay Jaf, J. M. S., Kepczynska, M. A., Wargent, E. T., Hislop, D. C. Cawthorne, M. A., Arch, J. R. S., et al. (2011). Developmental programming of pancreatic tissue by maternal high fat feeding. Diabetologia 54:S204. doi: 10.1007/ s12170-012-0257-x

Rodriguez-Trejo, A., Ortiz-Lopez, M. G., Zambrano, E., GranadosSilvestre Mde, L., Mendez, C., Blondeau, B., et al. (2012). Developmental programming of neonatal pancreatic betacells by a maternal low-protein diet in rats involves a switch from proliferation to differentiation. Am. J. Physiol. Endocrinol. Metab. 302, E1431-E1439. doi: 10.1152/ajpendo.00619.2011

Samuelsson, A. M., Matthews, P. A., Argenton, M., Christie, M. R., McConnell, J. M., Jansen, E. H., et al. (2008). Diet-induced obesity in female mice leads to offspring hyperphagia, adiposity, hypertension, and insulin resistance: a novel murine model of developmental programming. Hypertension 51, 383-392. doi 10.1161/HYPERTENSIONAHA 107.101477

Sander, M., and German, M. (1997). The beta cell transcription factors and development of the pancreas. J. Mol. Med. 75, 327-340. doi $10.1007 / \mathrm{s} 001090050118$

Sander, M., Sussel, L., Conners, J., Scheel, D., Kalamaras, J., Dela Cruz, F., et al. (2000). Homeobox gene Nkx6.1 lies downstream of
Nkx2.2 in the major pathway of beta-cell formation in the pancreas. Development 127, 5533-5540.

Sandovici, I., Hammerle, C. M., Ozanne, S. E., and Constancia, M. (2013). Developmental and environmental epigenetic programming of the endocrine pancreas: consequences for type 2 diabetes. Cell. Mol. Life Sci. 70, 1575-1595.

Sandovici, I., Smith, N. H., Nitert, M. D., Ackers-Johnson, M., UribeLewis, S., Ito, Y., et al. (2011). Maternal diet and aging alter the epigenetic control of a promoterenhancer interaction at the Hnf4a gene in rat pancreatic islets. Proc. Natl. Acad. Sci. U.S.A. 108, 5449-5454. doi: 10.1073/pnas. 1019007108

Schisler, J. C., Jensen, P. B., Taylor, D. G., Becker, T. C., Knop, F. K., Takekawa, S., et al. (2005). The Nkx6.1 homeodomain transcription factor suppresses glucagon expression and regulates glucosestimulated insulin secretion in islet beta cells. Proc. Natl. Acad. Sci. U.S.A. 102, 7297-7302. doi: 10.1073/pnas.0502168102

Schwitzgebel, V. M., Scheel, D. W., Conners, J. R., Kalamaras, J., Lee, J. E., Anderson, D. J., et al. (2000). Expression of neurogenin3 reveals an islet cell precursor population in the pancreas. Development 127, 3533-3542.

Schwitzgebel, V. M., Somm, E., and Klee, P. (2009). Modeling intrauterine growth retardation in rodents: impact on pancreas development and glucose homeostasis. Mol. Cell. Endocrinol. 304, 78-83. doi: 10.1016/j.mce.2009.02.019

Sharma, A., Moore, M., Marcora, E., Lee, J. E., Qiu, Y., Samaras, S., et al. (1999). The NeuroD1/BETA2 sequences essential for insulin gene transcription colocalize with those necessary for neurogenesis and p300/CREB binding protein binding. Mol. Cell. Biol. 19, 704-713.

Sharma, S., Leonard, J., Lee, S., Chapman, H. D., Leiter, E. H., and Montminy, M. R. (1996). Pancreatic islet expression of the homeobox factor STF-1 relies on an E-box motif that binds USF. J. Biol. Chem. 271, 2294-2299. doi: $10.1074 / \mathrm{jbc}$ 271.4.2294

Simmons, R. A. (2007). Developmental origins of beta-cell failure in type 2 diabetes: the role of epigenetic mechanisms. Pediatr. Res. 61(5 Pt 2), 64R-67R.

Smith, S. B., Gasa, R., Watada, H., Wang, J., Griffen, S. C., and German, M. S. (2003). Neurogenin3 
and hepatic nuclear factor 1 cooperate in activating pancreatic expression of Pax4. J. Biol. Chem. 278, 38254-38259. doi: 10.1074/jbc. M302229200

Sosa-Pineda, B. (2004). The gene Pax4 is an essential regulator of pancreatic beta-cell development. Mol. Cells 18, 289-294.

Srinivasan, M., Mitrani, P., Sadhanandan, G., Dodds, C., Shbeir-ElDika, S., Thamotharan, S., et al. (2008). A high-carbohydrate diet in the immediate postnatal life of rats induces adaptations predisposing to adult-onset obesity. J. Endocrinol. 197, 565-574. doi: 10.1677/JOE-080021

Stanfel, M. N., Moses, K. A., Schwartz, R. J., and Zimmer, W. E. (2005). Regulation of organ development by the NKX-homeodomain factors: an NKX code. Cell. Mol. Biol. (Noisy-le-grand). (Suppl. 51), OL785-OL799.

Stefan, Y., Grasso, S., Perrelet, A., and Orci, L. (1982). The pancreatic polypeptide-rich lobe of the human pancreas: definitive identification of its derivation from the ventral pancreatic primordium. Diabetologia 23, 141-142. doi: 10.1007/BF01271177

Stocker, C. J., Arch, J. R., and Cawthorne, M. A. (2005). Fetal origins of insulin resistance and obesity. Proc. Nutr. Soc. 64, 143-151. doi: 10.1079/PNS2005417

Sussel, L., Kalamaras, J., HartiganO'Connor, D. J., Meneses, J. J., Pedersen, R. A., Rubenstein, J. L., et al. (1998). Mice lacking the homeodomain transcription factor Nkx2.2 have diabetes due to arrested differentiation of pancreatic beta cells. Development 125, 2213-2221.

Tarry-Adkins, J. L., and Ozanne, S. E. (2011). Mechanisms of early life programming: current knowledge and future directions. Am. J. Clin. Nutr. 94(6 Suppl.), 1765S-1771S. doi: 10.3945/ajen.110.000620
Tasaka, Y., Matsumoto, H., Inoue, Y., and Hirata, Y. (1989). Contents and secretion of glucagon and insulin in rat pancreatic islets from the viewpoint of their localization in pancreas. Tohoku J. Exp. Med. 159, 123-130. doi: 10.1620/tjem.159.123

Thangaratinam, S., Rogozinska, E., Jolly, K., Glinkowski, S., Duda, W., Borowiack, E., et al. (2012). Interventions to reduce or prevent obesity in pregnant women: a systematic review. Health Technol. Assess. 16, iii-iv, 1-191.

Thompson, R. F., Fazzari, M. J., Niu, H., Barzilai, N., Simmons, R. A., and Greally, J. M. (2010). Experimental intrauterine growth restriction induces alterations in DNA methylation and gene expression in pancreatic islets of rats. J. Biol. Chem. 285, 15111-15118. doi: 10.1074/jbc.M109.095133

Vanhoose, A. M., Samaras, S., Artner, I., Henderson, E., Hang, Y., and Stein, R. (2008). MafA and MafB regulate Pdxl transcription through the Area II control region in pancreatic beta cells. J. Biol. Chem. 283, 22612-22619. doi: 10.1074/jbc.M802902200

Villasenor, A., Chong, D. C., and Cleaver, O. (2008). Biphasic Ngn3 expression in the developing pancreas. Dev. Dyn. 237, 3270-3279. doi: 10.1002/dvdy. 21740

Wang, J., Elghazi, L., Parker, S. E., Kizilocak, H., Asano, M., Sussel, L., et al. (2004). The concerted activities of Pax4 and Nkx2.2 are essential to initiate pancreatic betacell differentiation. Dev. Biol. 266, 178-189. doi: 10.1016/j.ydbio.2003. 10.018

Waterland, R. A., and Garza, C. (2002). Early postnatal nutrition determines adult pancreatic glucose-responsive insulin secretion and islet gene expression in rats. J. Nutr. 132, 357-364.

Wescott, M. P., Rovira, M., Reichert, M., von Burstin, J., Means, A., Leach, S. D., et al. (2009). Pancreatic ductal morphogenesis and the Pdx1 homeodomain transcription factor. Mol. Biol. Cell 20, 4838-4844. doi: 10.1091/mbc.E09-03-0203

Wessells, N. K., and Cohen, J. H. (1967). Early pancreas organogenesis: morphogenesis, tissue interactions, and mass effects. Dev. Biol. 15, 237-270. doi: 10.1016/00121606(67)90042-5

WHO. (2013). Obesity and Overweight. Available online at: http://www.who.int/mediacentre/fac tsheets/fs311/en Factsheet No 311 (Fact sheet) 2013 March 2013 (cited 2013 10th March 2013).

Yamaoka, T., and Itakura, M. (1999). Development of pancreatic islets (review). Int. J. Mol. Med. 3, 247-261.

Yang, Y., and Cvekl, A. (2007). Large Maf transcription factors: cousins of AP-1 proteins and important regulators of cellular differentiation. Einstein J. Biol. Med. 23, 2-11.

Yang, Y., Ding, L., An, Y., Zhang, Z. W., Lang, Y., Tai, S., et al. (2012). MiR-18a regulates expression of the pancreatic transcription factor Ptfla in pancreatic progenitor and acinar cells. FEBS Lett. 586, 422-427. doi: $\quad$ 10.1016/j.febslet.2012. 01.015

Yang, Z., and Huffman, S. L. (2013). Nutrition in pregnancy and early childhood and associations with obesity in developing countries. Matern. Child Nutr. 9(Suppl. 1), 105-119. doi: $10.1111 / \mathrm{mcn}$. 12010

Zambrano, E., Bautista, C. J., Deas, M., Martinez-Samayoa, P. M., Gonzalez-Zamorano, M., Ledesma, H., et al. (2006). A low maternal protein diet during pregnancy and lactation has sex- and window of exposure-specific effects on offspring growth and food intake, glucose metabolism and serum leptin in the rat. J. Physiol. 571(Pt 1), 221-230.

Zhang, C., Moriguchi, T., Kajihara, M., Esaki, R., Harada, A.,
Shimohata, H., et al. (2005). MafA is a key regulator of glucose-stimulated insulin secretion. Mol. Cell. Biol. 25, 4969-4976. doi: $\quad$ 10.1128/MCB.25.12.49694976.2005

Zhang, L., Long, N. M., Hein, S. M., Ma, Y., Nathanielsz, P. W., and Ford, S. P. (2011). Maternal obesity in ewes results in reduced fetal pancreatic beta-cell numbers in late gestation and decreased circulating insulin concentration at term. Domest. Anim. Endocrinol. 40, 30-39. doi: 10.1016/j.domaniend.2010.08.004

Zhou, Q., Law, A. C., Rajagopal, J., Anderson, W. J., Gray, P. A., and Melton, D. A. (2007). A multipotent progenitor domain guides pancreatic organogenesis. Dev. Cell 13, 103-114. doi: 10.1016/j.devcel.2007.06.001

Conflict of Interest Statement: The authors declare that the research was conducted in the absence of any commercial or financial relationships that could be construed as a potential conflict of interest.

Received: 14 March 2013; accepted: 18 June 2013; published online: 18 July 2013.

Citation: O'Dowd JF and Stocker CJ (2013) Endocrine pancreatic development: impact of obesity and diet. Front. Physiol. 4:170. doi: 10.3389/fphys. 2013.00170

This article was submitted to Frontiers in Integrative Physiology, a specialty of Frontiers in Physiology.

Copyright (c) 2013 O'Dowd and Stocker. This is an open-access article distributed under the terms of the Creative Commons Attribution License, which permits use, distribution and reproduction in other forums, provided the original authors and source are credited and subject to any copyright notices concerning any third-party graphics etc. 